\title{
Value Added Tax Administration and Its Challenges: The Case of South Gondar Zone, Ethiopia
}

\author{
Alebel Woretaw \& Dejen Debeb \\ Lecturer, Faculty of Business \& Economics, Debre Tabor University, Debre Tabor, Ethiopia
}

\begin{abstract}
Tax contributions are important for different public services such as security, health, education, building infrastructures and welfare programs. The growth of global economy has been another factor leading to change in the tax system. As the result tax is the main source of revenue for both developed and developing nations to maximize their economic development as well as national security. Taxes have usually two parts, direct tax and indirect tax, according to the point at which they are actually paid. One of the main parts of indirect tax is VAT. The main objective of this study is to investigate the main Value Added Tax administration challenges of South Gondar Zone. Mainly primary source of data were used in this study. Two main target groups were identified; taxpayers and tax officers. In the study, 384 tax payers who are registered for VAT and 102 tax officers were interviewed. The awareness level of the tax payers towards VAT was one point of interest and results show that out of the 102 tax officers, most of them reported that the awareness of the tax payers is low. Based on the results of the findings, the main challenges of Value Added Tax administration in South Gondar Zone are: lack of tax payers awareness, selling goods and services without tax invoice or lack of use proper Value Added Tax invoices, weak culture of taxpayers, and lack of fairness, lack of experience of Value Added Tax registrants, weak followups and controlling mechanisms against those unregistered and registered Value Added Tax payers. To alleviate awareness problem there is a need to have tax education campaign by coordinated efforts that must be exerted at all levels to enhance the awareness of the tax payers and other members of the community. The major task that the office should do is supervising and monitoring of those whether unregistered and registered Value Added Tax taxpayers up to door to door inspection. There is a need to enhance the capacity of the employees of the tax office. Of course, the study shows that both short term and long term trainings are given. But still, there is also a need for changing the attitude towards customer handling and other service giving methodologies.
\end{abstract}

Keywords: Vat, administration, challenges

DOI: $10.7176 / \mathrm{JESD} / 10-23-03$

Publication date: December $31^{\text {st }} 2019$

\section{BACKGRAUND OF THE STUDY \\ Introduction}

Different attempts have been made by variants of writers in order to define the term 'tax' since its introduction. Dalton (1991) defines tax as "a compulsory contribution imposed by a public authority, irrespective of the exact amount of service rendered to the taxpayer in return." Bhatia(2003) also defines the word tax "as a compulsory legal levy payable by an economic unit to the government without any corresponding entitlement to receive a definite and direct quid pro quo from the government for the contribution made. Tax is the money that you have to pay to the government so that it can pay for public services. People pay tax according to their income and businesses pay tax according to their profits. Tax is also often paid on goods and services (Oxford, 2010).

Tax assessment refers to the initial review by the tax authority of the tax declaration and attached supplementary documents submitted by a taxpayer and verification of the arithmetical and technical accuracy of the declared tax liability and tax payable shortly after the submission of the declaration .once an income declaration is checked and verified by the concerned tax authority through a process called income tax assessment, hence, tax assessment is the end result of the process of ascertaining a tax payer's taxable income and the tax payable on that income(Tesfaye et al,2014).

Tax administration is the identification of tax liability based on the existing tax law, the assessment of this liability, and the collection, prosecution and penalties imposed on recalcitrant taxpayers. Tax administration, therefore, covers a wide area of study, encompassing aspects such as registration of taxpayers, assessments, and collection (Kangave, 2005).

Governments, all over the world have their stated number of public projects, such as social security protection and other services of public utilities like electricity, water supply, rail ways, heavy electrical, atomic energy, etc. As Eric (2008) stated, common expenditure programs include health and welfare programs, defense spending, social security, and interest and repayment of principal on government debt. Under this view, the role of the tax system is to raise an amount of revenue that is tied to the level of government services. For those countries with significant sources of revenue other than taxes, government can fund operations with less reliance on current tax revenue.

Governments in low income countries have the difficult task of making wide-ranging decisions about public 
spending, taxation, and borrowing in aim of helping their countries maintain long-term debt sustainability, achieve higher economic growth, and ultimately reduce poverty. One of the challenging factors of implementing policies is raising public revenues which is difficult in a context of macroeconomic and growth instability, high debt ratios, weak tax administration, and large informal sectors (Eric, 2008).

A tax is a liability imposed up on the tax assesses who may be individuals, groups of individuals, or other legal entities. It is a liability to pay an amount on account of the fact that the tax assesses have income of a minimum amount and from certain tangible or intangible property, or that they carry on certain economic activities which have been for taxation (Bhatia,2008). Taxes are generally categorized into two as direct and indirect taxes. VAT is categorized under indirect taxes.

Fifty years ago the Value Added Tax (VAT) was rarely heard outside of France and a few dry specialist texts. Now it raises about 20 percent of the world's tax revenue, and affects about 4 billion people (Keen and Lockwood, 2007). Few fiscal issues are more important in developing and transitional economies (DTE) than the Value Added Tax (VAT).

Over the last few decades, VAT has swept the world. The principal reasons for the rapid of this form of taxation were, first, the early adoption of this form of taxation in developing and transitional economies (DTE) by the International Monetary Fund (IMF) in particular and by international agencies and advisors in general (Richard, 2006).

The concept of value added tax was generated in 1954 by a French economist Maurice Laurie who was joint director of the French tax authority. The theory is that the end consumer carries the burden of Value Added Tax, not the business, which is merely collecting the Value Added Tax on behalf of tax authority. Different scholars also define value added tax as a percentage tax on a value added applied at each stage of production. It is a type of indirect tax, nowadays found in more than 130 countries and has become the principal source of revenue for many countries (Kassu, 2011).

VAT is defined as broad-based tax levied on commodity sales up to and including, at least, the manufacturing stage, with systematic offsetting of tax charged on commodities purchased as inputs-except perhaps on capital goods-against that due on outputs (Ebrill, et al, 2001 ). It is a tax levied and collected on sales of goods and services, with systematic offsetting of tax charged on goods and services purchased as inputs against that due on outputs.

VAT is a tax compulsory levy and those who are taxed have to pay the sums irrespective of any corresponding return of services or goods by the government. In other words, a taxpayer does not receive a definite and direct quid pro quo from the government.

Despite its name, VAT is not generally intended to be a tax on the value added; rather it is usually intended as a tax on consumption. The tax is charged at all stages of production and distribution chain, beginning with importers and producers and ending with retailers, with the provision of some mechanism enabling firms to offset the tax they have paid on their own purchases against the tax they charge on their sales. This feature of the tax makes VAT to be a broad- based tax levied at multiple stages of production and distribution - unlike a retail sales tax that VAT replaced in most countries.

Some of the benefits of VAT include such as removing the tax content (on inputs) from exported goods makes the goods more competitive in international markets; domestically produced goods will be more competitive with imported goods; relief from tax on capital goods will encourage investment; and Value Added Tax (VAT) raises more government revenue than the replaced Sales Tax. In line with this, the vision of the Ethiopian Government is to bring rapid and sustainable development, The achievement of this rapid and sustainable development objective mainly requires sustainable and dependable domestic revenue mobilization which otherwise will be a dream to realize the Government's vision depending on external finance sources, which is subject to uncertainty. Indeed, this does not mean external sources are not important; rather it is to stress the fact that domestic resource should take the largest share in financing development endeavors in developing economies.

Emergence and rapid spread of Value Added Tax (VAT) is one among the most important tax developments of the later twentieth century. VAT was first introduced as a comprehensive national tax in France in the 1950s. Since then it has been adopted as the main form of an indirect taxation by many countries in different parts of the world and at different stages of economic development. These days it is a key source of government revenue in over 130 countries.

According to IMF (2013) more than 4 billion, 70 percent of the world's population now lives in countries with VAT, and it raises about \$ 18 trillion in tax revenue, roughly one quarter of all government revenue. Much of its spread has taken place over the last fifteen years from having been the preserve of more developed economies in Europe and Latin America; it has become a pivotal component of the tax systems of both developing and transition economies.

Being major component of country's tax system the VAT has been seen as a key instrument for securing Macro-economic stability and growth by placing domestic revenue mobilization on a sounder basis, so that countries have attached considerable importance to its proper design and implementation. Considering these merits the tax system deserves, Ethiopia has adopted as a major component of the ongoing Tax System Reform Program 
(TSRP) since January 1, 2003. In order to realize the above objectives the Ethiopian Government acknowledged that successful implementation of the overall Tax reform program including the VAT was vital to attaining the economic and social objectives, through the mobilization of its own domestic resources. The introduction of the VAT on January 1, 2003 to replace the sales tax is one of the components of the tax reform program.

The adoption of the VAT is also consistent with the direction that many countries have been taking in shifting away from the reliance on direct takes towards a VAT. The successful implementation of the VAT was dependent upon the effective management of the process, the conveyances of a comprehensive understanding of the scope and benefits of the VAT to the business community, other stakeholders and the consumers; and the establishment of an effective tax administration.

Tax administration pertains to the duties and responsibilities of tax officials in identification and registration of taxpayers, processing returns, controlling collections, securing of delinquent declarations and collection of tax arrears, making refunds, auditing taxpayers, investigating for tax fraud and evasion, and levying penalties.

According to International Monetary Fund report in the year 2004, about 136 countries have made Value Added Tax part of their tax system, and from 53 member of countries of African Union 33 of them introduced Value Added Tax as their tax system (Wotku, 2008).

Value-added tax falls under the general category of a consumption tax, meaning taxes are paid on what people buy rather than on their earnings, savings, or investments. VAT has also been referred to as a sort of national sales tax, though it functions very differently. Sales tax is imposed on the total (Encyclopedia of Management, 2009)

The Federal Democratic republic of Ethiopia (FDRE) has adopted VAT into its tax system in 2003. It has been introduced on January 1, 2003, replacing the former sales tax system. The VAT proclamation NO 285/2002/ (VAT law) has been ratified by the house of peoples Representatives six months before VAT implementation (July, 2002). This VAT proclamation has thirteen sections (13) and sixty-six (66) articles. In December, 2002, the VAT regulation No 79/2002 has also been issued by Council of Minister pursuant to the value add tax proclamation for the implementation and regulation of VAT. The VAT regulation has three chapters (3) and forty (40) articles. VAT is introduced in Ethiopia by proclamation NO 285/2002, replacing sales tax with the following objectives:

- To collect tax on the added value whenever a sales transaction is conducted since the former sales tax system already replaced did not allow collection of the tax on the added value created whenever sales transaction is conducted

- To minimize the Damage that may be caused by attempts to avoid and evade the tax and to ascertain the profit obtained by the tax taxpayers

- To enhance saving and investment as it is a consumption tax and does not tax capital and.

- To enhance economic growth and improver the ration relationship between gross Domestic product and gross revenue.

According to the newly implemented VAT law supply of goods and rendition of services in Ethiopia are subject to VAT at a standard rate of $15 \%$ except those exempted and zero-rated is supplies determined by the VAT law. The standard rate, $15 \%$ is applied only to imports and domestically manufactured goods (Misrak, 2008).

Unlike the sales tax, VAT provides the relief of the tax on all business in puts (taxable supply) including capital goods operating and administrative expenditures. The relied of the tax and zero rating also encourages investment and exports. The VAT system that Ethiopia has implemented also gives exemption to basics and necessities such education medical service electricity water kerosene, basic foods, transportation service fertilizers books and printed materials the supply of goods or services in the form of humanitarian aid etc.(Misrak, 2008).

However, weak tax administration, particularly in developing and transitional economies is the principal impediment to the successful implementation of Value Added Tax the case is not exceptional in Ethiopian context.

\section{Objectives of the study General Objective}

The general objective of this study is to investigate the VAT administration and challenges of Value Added Tax in South Gondar Zone.

\section{Specific Objectives}

The following specific objectives were pursued.

- To identify demographic factors of tax payers that affect VAT administration activities of South Gondar Zone Revenue Office.

- To identify socio economic challenges of tax payers that affect monitoring and auditing of VAT registrant in South Gondar Zone.

- To investigate administrative factors those affect South Gondar Zone Revenue Office to monitor and audit VAT registrants. 


\section{RESEARCH METHODOLOGY}

\section{Research Design}

In terms of research design, this study will use descriptive types of research which will be used to identify and obtain information related to features of research problem. The basis for selecting this type of research method is that the study will not have a control on the variables; rather it describes the characteristic of the South Gondar zone Revenue Authority Office Value-added Tax administrative activities and to answer the question what is the best way to administer the Value Added Tax in order to assess and collect the potential revenue from the Zone. .

\section{The Study Area}

The study was conducted in south Gondar Zone. South Gondar Zone is found in Amhara Regional state, Ethiopia which is $625.04 \mathrm{~km}$ away from Addis Ababa the capital city of Ethiopia. This zone is named for the city of Gondar, which was the capital of Ethiopia until the mid-19th century and has often been used as a name for the local province. South Gondar is bordered on the south by Misraq Gojjam, on the southwest by Mirab Gojjam and Bahir Dar, on the west by Lake Tana, on the north by Semien Gondar, on the northeast by Wag Hemra, on the east by Semien Wollo, and on the southeast by Debub Wollo; the Abbay River separates South Gondar from the two Gojjam Zones.

The highest point in South Gondar is Mount Guna (4,231 meters). In the Zone there are 13 woredas such as Farta, Fogera, Estie, Simada, Sediemuja,Guna Begemidir,Tachgaint, Laygaint, Dera, Debre Tabor, Libo kemkem, Ebnat, Andabet and 4 Towns Administration namely Nefasmewuch, addiszemen, woreta and MekaneEyesus.

\section{Target Population}

The population of study constitutes 2111 VAT registered taxpayers found in the 13 districts and 4 town administrations of South Gondar Zone.

\section{Sampling Procedure}

This study used stratified random sampling technique. 13(thirteen) strata were formed by merging the 4 town administrations to the nearby districts (i.e, Nefeas Mewcha with Lay Gayent,Addis Zemene with Libokemekem, Woreta with Fogera and MekaneEyesus with Estie) and random sampling technique will be applied to select respondents from each strata. The sample required from each stratum was determined through proportional approach.

$$
\text { i.e.; } n_{i}=\frac{n^{*} N_{i}}{N}
$$

Where; $\mathrm{n}_{\mathrm{i}}=$ proportionate sample size for the $\mathrm{i}^{\text {th }}$ district under each catagory, $\mathrm{n}=$ determined sample size, $\mathrm{N}_{\mathrm{i}}=$ portion of the population in the $\mathrm{i}^{\text {th }}$ district for each category and $\mathrm{N}=$ total population for each category.

The samples required from each district in proportion to the total population are determined as follows.

\begin{tabular}{|l|l|l|l|l|}
\hline District & Category A & Proportionate Share & Category B & Proportionate Share \\
\hline Farta & 26 & 4 & 94 & 15 \\
\hline D/Tabor & 266 & 41 & 368 & 142 \\
\hline Simada & 58 & 9 & 61 & 9 \\
\hline Fogera & 87 & 14 & 278 & 43 \\
\hline Libokemekem & 62 & 10 & 146 & 23 \\
\hline Estie & 63 & 10 & 243 & 138 \\
\hline TachGayent & 35 & 5 & 17 & 3 \\
\hline Ebenat & 53 & 8 & 130 & 64 \\
\hline Lay Gayenet & 203 & 16 & 109 & 37 \\
\hline Andabet & 113 & 2 & 49 & 48 \\
\hline Dera & 13 & 2 & 97 & 15 \\
\hline Total & $\mathbf{7 1 7 9}$ & $\mathbf{1 2 1}$ & $\mathbf{1 3 9 2}$ & 384 \\
\hline
\end{tabular}

Source: South Gondar Zone Revenue Office Base Line Data, 2018

\section{Sample Size}

The sample size is determined using a scientific formula obtained from Adams et.al (2007) to determine the sample size for cross-sectional studies. The formula used is as follows:

$n=\frac{N}{1+N e^{2}}$

Where; $\mathrm{n}=$ sample size $\mathrm{N}=$ Total population $\mathrm{e}=$ Error tolerance. 
The margin error for this study is $5 \%$, and using this information, the sample size is equal to:

$n=\frac{2111}{1+2111(0.05)^{2}}=384$

\section{Research Instruments}

This study used both primary and secondary data. The study used questionnaire and FGD to collect all required information for further analysis. To collect data 20 data collectors were employed. The questionnaire was used to accommodate questions to be answered by VAT registered taxpayers. Four FGD were conducted with respondents for clarification on challenges of VAT administration issues. Secondary data was collected from available documents of each district revenue administration office.

\section{Data analysis techniques}

The data was analyzed and interpreted using descriptive statistics method with table, charts, and figure and percentages using Statistical Package for Social Sciences (SPSS) software. It is used to minimize errors that can occur during data processing and analysis by manual computations.

\section{Results and discussion \\ Responses from the Taxpayers \\ Background information}

The socioeconomic and demographic characteristics of the respondents determine their attitude and their attitude in turn determines the way they react to policies and strategies. VAT is one of the newly introduced mechanisms of generating revenue and was introduced before seven years. At the beginning of the introduction of the VAT, some sort of resistance was observed. But, after exerting efforts, changes were observed. But still observations show that there are some members of the business community who resisted to get registered for VAT. Sex, age, educational level and other factors are expected to influence the attitude of the respondents towards such newly introduced policies and strategies.

In the study, 384 tax payers who are registered for VAT were interviewed. Out of these, 304 (79.20 percent) were males and 80 (20.8 percent) were females.

When we look at the type of ownership of the organizations studied, 345 (89.85 percent) were sole proprietorship and the remaining 39 (10.15percent) were having legal entity.

The average age of the respondents was also calculated and results show that female respondents are younger (by at least 5 years) than the male respondents. The mean, median and modal ages of the respondents are 29 years, 31 years and 24 years respectively.

The maximum age of the respondents is 72 years. The mean age of the respondents is 43.56 . In addition, the median age of the males and the females is 33 years. The modal age of the males and females is 35 years.

\section{Distribution of respondents by educational level}

This refers to the grades completed through formal schooling. It was considered that a member having longer years of formal schooling could have a better awareness and knowledge about taxation and in turn he/she would increase his intention to pay Vat on time and exact amount. As to table 4 below, it was found that from the total respondents about $23.3 \%$ were illiterate, $10.5 \%$ were able to read and write, $21.1 \%$ belonged to grade $1-4,37.6 \%$ were between grade 5 and 8 and the rest $7.5 \%$ were between grades $9-12$. This implies the vast majority of the respondents had no problem of reading and writing.

The distribution of the VAT payers of the sample, that most of the VAT payers in the study area concentrated in the areas of Service sector and Merchandise business types which made up almost $88 \%$, while the manufacturing affiliated VAT payers constituted only $12 \%$.

The information as to how the VAT payers learned about the beginning of the VAT system of taxation in their administrative zones are diverse. As per the data of the respondents, it reveals that there was no information approach which served the creation of awareness of the VAT system to the VAT payers. Out of the total respondents 352(91.8\%) confirmed that they have had attended government training program regarding the implementation and guidelines of the VAT system by concerned government authorities, while it was responded that $14(4.1 \%)$ of them were able to learn about VAT from media channels. On the other hand, $18(4.68 \%)$ of them responded that they have had no formal channel either from media or training and just learned from their direct experience of VAT payment which they were requested to be involved in by government VAT implementing authorities. The data shows that the government authorities were first able to create the awareness on VAT system to potential VAT Payers before the implementation of the VAT system into practice.

It is very important to know as to what is the perception of the VAT payers as to the benefit VAT can bring to the economy and how it benefits the government and private sectors. The response to the question as to who 
benefits from VAT tax collection shows not all VAT tax payers have the same understanding. 294(76.82\%) of the VAT payers responded that they think the government is the primary beneficiary while only $45(11.62 \%)$ responded that the society is the primary beneficiary. 44(11.56.3\%) of the respondents on the other hand responded that both the society and the government are both beneficiaries of the VAT system, while none of the respondents have forwarded that businesses/investors are the sole beneficiary of the system.

The data shows that while the intent that the benefit of the system goes to the society, most of the respondents felt that the government is the sole beneficiary of the system. Hence, there is a need for more creation of awareness on VAT payers as to the fact that VAT is important source of revenue of the government and yet the ultimate beneficiary is the society. Thus, it is evident from this responses that there is a need for campaigns by government authorities in reshaping this perception of some VAT payer sections of the businesses that believe that government is the only beneficiary of the VAT revenue.

In relation to creating healthy and correct perceptions on the VAT payment system, it is very understandable that the first step is creating the awareness of the importance of registration of VAT for those who are eligible to VAT paying status. The result for the request on the approval of businesses on their registration of VAT payment system is very suggestive on the fact that although the government authorities have disseminated information on the importance of VAT to VAT Paying businesses, the required correct perception on the system and the willful registration of the businesses has not yet come to the desired level. This is indicated on the data from Table 4.4, that only $59(15.36 \%)$ of the respondents positively answered that they had positive approval for the registration of VAT while the significant respondents went on explaining they were not registered with their willpower interest to the VAT system. The implication could be that, the habit and willingness to pay the required income tax based on value added income has not yet taken root into the perception of VAT paying businesses. This is also an indication that there is a need to exert more effort into alleviation of this perception problem by the concerned government authorities. Most of the respondents who do not support of being registered for VAT were also asked to pass on their reasons and they have forwarded different reasons which can be summarized into the following points:-

- Since, there are many unregistered business firms, many of their customers have shifted to those firms and as a result, their sales/revenue has deteriorated significantly since

- Similarly, as the controlling system of the authority is not well-developed, there are different business firms in selling their product and services VAT free which is affecting their businesses badly.

- Some few respondents have also explained that the introduction of VAT has brought them different complexities in their day-to-day activities and their record keeping system. As a result, they have been forced to hire additional professional employees which therefore imposed them to incur additional costs.

It is understandable the extent of success in settling VAT payments depends on the sophistication of the mode of payment. As is known, the more the modern the VAT paying and receipts registration system is, the more is the smooth and tamely settlement of the payment is expected to be. The result on this regard showed that out of the sampled 384 VAT paying businesses, 215(55.99\%) of them are using cash registration machine while the rest, $169(44.01 \%)$ of them use the manual cash receipt record papers. This shows that as most VAT payer business are located in electrified major towns, there is a significant task to incorporate the use of registration machines so that the VAT system will be effective in minimizing VAT tax evasions

But, not every VAT payer believes he/she is in a position to incorporate the modern system due to different reasons. $105(31.82 \%)$ of the respondents revealed that they don't have the ability to afford to purchase the VAT registration machine while $14(12.12 \%)$ of them explained that the machine is not available for them in their nearby market system and majority of the respondents $40(56.06 \%)$, are on a waiting list to purchase the machine. This suggests that government concerned authorities need to facilitate the ownership of the VAT registration machine either by providing loan or facilitating the availability of those machines to the VAT payers and increase the supply of the machine as well. Moreover, there may be a need for clear standards as to which VAT payer businesses should be already able to possess the machine and start their payment in modern system based on their VAT income level.

The fact the manual receipt system depends on the approval of the receipt papers from the nearby Tax and Revenue authority offices and as the businesses have to responsibly provide themselves with the receipt notes, it is very important to identify how the businesses react to situations when they run out of the receipts. Out of the total manual cash receipt users, 65 of them have reported they face situation where they run out of the receipt notes while the rest 33 reported they have not came across this problem as they in time demand extra receipts from the revenue authority when they find it they are running out of it. The result on this issue showed that $75(19.53 \%)$ of the VAT payers that face the problem prefer not to charge VAT at such incident and offer VAT free service to customers, $98(25.52 \%)$ of them register it in separate record and charge VAT payment on their services while the rest $211(54.95 \%)$ of the respondents stated they explain the case to their customers and charge prices without VAT. This would mean that whether they inform to their customers or not, at such situations, most of them are abstaining from implementing the VAT system and government is not getting the legally required VAT tax as it should be. 
This suggests that there is a need to ensure the supply of cash receipt notes from the revenue authorities must be maintained uninterrupted and strict punishments shall be enforced on those who don't provide customers on time the VAT receipt notes.

\section{Responses from the Tax Officers}

252 tax officers were also given questionnaires about the VAT administration and its challenges in the study area. The specific job of the tax officers were also studied and it includes tax auditors, finance officer, tax refund supervisors, record team leader, complaints officer, accounts officer, process owner of tax collection and enforcement process, process owner of customer service center process.

Out of the 252 tax officers, 16 had diploma, 233 had first degree and 3 had second degree.

It can be said that almost all of the tax officers have the needed educational background.

\section{Awareness of the tax payers towards VAT as reported by the tax officers}

The awareness of the tax payers towards VAT was one point of interest and results show that out of the 252 tax officers, only 6 reported that the awareness of the tax payers is high and 15 reported that the awareness is average. In addition, 145 tax officers reported that the awareness is low and 86 explained that the awareness of the tax payers towards VAT is very low. Some of the reasons for the low awareness as explained by the officers are given below.

$\checkmark \quad$ The tax payers do not appear to the training sessions arranged by the office.

$\checkmark$ Tax payers are not ready to read and then update themselves about new rules, regulations and proclamations about VAT and other forms of tax.

$\checkmark \quad$ Tax payers have low educational level and cannot cope up with the situations.

In most case, failure give VAT receipts up on payment, giving used VAT receipts are the major ways of tax evading mechanisms used by the VAT registered tax payers. Some business enterprises also use power failure and unavailability of VAT receipts as reasons and as a means to evade the VAT revenue that would have been an income to the government and the country. In relation to this, many of the respondents suggest that the concerned government bodies should design a strong controlling mechanism and penalize those involved in such an activity. Moreover, the sample respondents were asked to forward the core ways of evasion, accordingly, 202(36\%) respondents revealed that the business firms did not bring them receipts upon payments, $182(16.6 \%)$ of the respondents stated that the business firms brought them other customers' receipt, of the respondents have noted that the business come up with power interruption or they run out of receipts as reasons, respectively.

\section{Conclusion and recommendations}

\section{Conclusion}

Mainly primary source of data was used in this study. Two main target groups were identified; taxpayers and tax officers. In the process, 15 enumerators were used and the enumerators were given detailed training about what each question intends to mean an on how to present it in-front of the informant. Questionnaires were also distributed to the randomly selected tax officers.

In the study, 384 tax payers who are registered for VAT were interviewed. Out of these, 304 (79.20 percent) were males and 80 (20.8 percent) were females. The type of ownership of the organizations studied, 345 (89.85 percent) were sole proprietorship and the remaining 39 (10.15percent) were having legal entity.

The average age of the respondents was also calculated and results show that female respondents are younger (by at least 5 years) than the male respondents. The mean, median and modal ages of the tax payer respondents are 29 years, 31 years and 24 years respectively. The maximum age of the tax payer respondents is 72 years. The mean age of the tax payer respondents is 43.56. In addition, the median age of the males and the females is 33 years. The modal age of the males and females is 35 years.

It was found that from the total tax payer respondents about $23.3 \%$ were illiterate, $10.5 \%$ were able to read and write, $21.1 \%$ belonged to grade $1-4,37.6 \%$ were between grade 5 and 8 and the rest $7.5 \%$ were between grades 9-12. This implies the vast majority of the respondents had no problem of reading and writing.

The sampling of the VAT tax payers was thus aimed at identifying the major factors that affect the process of effective payment, its fairness and all inclusiveness through the eyes of VAT payers. Most of the VAT tax payers in the study area concentrated in the areas of Service sector and Merchandise business types.

As per the responses of the respondents, it reveals that there was no information approach which served the creation of awareness of the VAT system to the VAT payers. Out of the total respondents $352(91.8 \%)$ confirmed that they have had attended government training program regarding the implementation and guidelines of the VAT system by concerned government authorities, while it was responded that $14(4.1 \%)$ of them were able to learn about VAT from media channels. On the other hand, 18(4.68\%) of them responded that they have had no formal channel either from media or training and just learned from their direct experience of VAT payment which they were requested to be involved in by government VAT implementing authorities. The data shows that the 
government authorities were first able to create the awareness on VAT system to potential VAT Payers before the implementation of the VAT system into practice.

The response to the question as to who benefits from VAT tax collection shows not all VAT tax payers have the same understanding. 294(76.82\%) of the VAT payers responded that they think the government is the primary beneficiary while only $45(11.62 \%)$ responded that the society is the primary beneficiary. $44(11.56 .3 \%)$ of the respondents on the other hand responded that both the society and the government are both beneficiaries of the VAT system, while none of the respondents have forwarded that businesses/investors are the sole beneficiary of the system.

The result shows that while the intent that the benefit of the system goes to the society, most of the respondents felt that the government is the sole beneficiary of the system. Hence, there is a need for more creation of awareness on VAT payers as to the fact that VAT is important source of revenue of the government and yet the ultimate beneficiary is the society.

The result for the request on the approval of businesses on their registration of VAT payment system is very suggestive on the fact that although the government authorities have disseminated information on the importance of VAT to VAT Paying businesses, the required correct perception on the system and the willful registration of the businesses has not yet come to the desired level. This is indicated that only $59(15.36 \%)$ of the respondents positively answered that they had positive approval for the registration of VAT while the significant respondents went on explaining they were not registered with their willpower interest to the VAT system. The implication could be that, the habit and willingness to pay the required income tax based on value added income has not yet taken root into the perception of VAT paying businesses. This is also an indication that there is a need to exert more effort into alleviation of this perception problem by the concerned government authorities.

The result shows that $105(31.82 \%)$ of the respondents revealed that they don't have the ability to afford to purchase the VAT registration machine while 14(12.12\%) of them explained that the machine is not available for them in their nearby market system and majority of the respondents $40(56.06 \%)$, are on a waiting list to purchase the machine. This suggests that government concerned authorities need to facilitate the ownership of the VAT registration machine either by providing loan or facilitating the availability of those machines to the VAT payers and increase the supply of the machine as well. Moreover, there may be a need for clear standards as to which VAT payer businesses should be already able to possess the machine and start their payment in modern system based on their VAT income level.

The result on this issue of actions taken when tax payers are out of receipts showed that $75(19.53 \%)$ of the VAT payers that faced the problem prefer not to charge VAT at such incident and offer VAT free service to customers, $98(25.52 \%)$ of them register it in separate record and charge VAT payment on their services while the rest $211(54.95 \%)$ of the respondents stated they explain the case to their customers and charge prices without VAT. This would mean that whether they inform to their customers or not, at such situations, most of them are abstaining from implementing the VAT system and government is not getting the legally required VAT tax as it should be. This suggests that there is a need to ensure the supply of cash receipt notes from the revenue authorities must be maintained uninterrupted and strict punishments shall be enforced on those who don't provide customers on time the VAT receipt notes.

Totally 252 tax officers were also given questionnaires about the VAT administration and its challenges in the study area. The specific job of the tax officers were also studied and it includes tax auditors, finance officer, tax refund supervisors, record team leader, complaints officer, accounts officer, process owner of tax collection and enforcement process, process owner of customer service center process. Out of the 252 tax officers, 16 had diploma, 233 had first degree and 3 had second degree. It can be said that almost all of the tax officers have the needed educational background.

The awareness of the tax payers towards VAT was one point of interest and results show that out of the 252 tax officers, only 6 reported that the awareness of the tax payers is high and 15 reported that the awareness is average.

In addition, 145 tax officers reported that the awareness is low and 86 explained that the awareness of the tax payers towards VAT is very low. Some of the reasons for the low awareness as explained by the officers are: The tax payers do not appear to the training sessions arranged by the office, tax payers are not ready to read and then update themselves about new rules, regulations and proclamations about VAT and other forms of tax and tax payers have low educational level and cannot cope up with the situations.

In most case, failure give VAT receipts up on payment, giving used VAT receipts are the major ways of tax evading mechanisms used by the VAT registered tax payers. Some business enterprises also use power failure and unavailability of VAT receipts as reasons and as a means to evade the VAT revenue that would have been an income to the government and the country. In relation to this, many of the respondents suggest that the concerned government bodies should design a strong controlling mechanism and penalize those involved in such an activity. 


\section{Recommendations}

Based on the findings given above, the following recommendations are made. Different types of challenges are observed during the administration of the VAT. One of the main challenges as explained by the taxpayers and tax officers is attitudinal problem. It seems that the tax payers have some attitudinal problems towards VAT. Results show that most of the problems emanate from lack of awareness and information. This is the main challenge that the VAT administration has faced in the process. Hence, coordinated efforts must be exerted (at all levels) to enhance the awareness of the tax payers and other members of the community.

Nearly two-third of the taxpayers and all of the tax officers has reported that the tax office has so many problems that demand change and improvement. It is the belief of the researchers that if the recommendations included in the designing stage of the BPR are properly implemented, radical changes would be observed. Therefore, the branch office has to study and assess possible reasons that hinder the full implementation of the $\mathrm{BPR}$ and then take appropriate measures.

There is need to enhance the capacity of the employees of the tax office. Of course, the study shows that both short term and long term trainings are given. But still, there is a need for changing the attitude towards customer handling and other service giving methodologies. Each employee has to be convinced that developing his/her own capacity is a continuous process and each of them has to take responsibility of doing so using different mechanisms.

\section{References}

- Gebrie work. ( 2006). Tax accounting in Ethiopia In context, $1^{\text {st }}$ edition, AAU, Ethiopia.

- Hussein,(2003).VAT introduction unexpected price increase noticed capital, $5^{\text {th }}$ edition.

- IMF. (2003). Social Impacts of a Tax Reform: The Case of Ethiopia. Washington.

- Kassu, T. (2011). Challenges of tax administration in Arada sub city Administration. Thesis Submitted to Addis Ababa University.

- Misrak Tesfaye. (2008), Ethiopia tax accounting theory and practice, Ethiopia.

- Negarit Gazzeta, proclamination No 285/2002 Addis Ababa: Bole printing press.

- Singh, V. (2003). Malaysian Tax Administration. (6 ${ }^{\text {th }}$ ed). Kuala Lumpur: Logman.

- Worku, G. (2008). Tax Accounting in Ethiopia, Addis Ababa: Alem Printing Press.

- Workineh A. (2016). Determinants of Tax revenue in Ethiopia (Johansen Co integration Approach).International Journal of Business, Economics and Management, 3(6)

- Yankelovich, Skelly and White. (1984). Taxpayer attitudes study: Final report. Public opinion survey prepared for the Internal Revenue Services. Washington, DC: Internal Revenue Service.

- Yesegat W. (2008) Value Added Tax Administration in Ethiopia. A Reflection of Problems, Accessed 16 Nov.2017 